\title{
Evaluating the Egyptian Official online channels for branding Egypt as a tourism destination
}

\author{
Lamiaa Hefny
}

Faculty of Tourism \& Hotel management

Pharos University in Alexandria

\begin{abstract}
Websites, social media, and tourism mobile applications are now considered important online channels for promoting destinations' brand. The study employed content analysis technique to analyze the official Egyptian Tourism Website, social media tools and the mobile application linked to the website. The study used three analysis models to evaluate the features and the interactivity of the Egyptian online channels. Results show a strong need to develop the interactivity of the Egyptian website and its mobile application. The study demonstrated the need for more integrated social media tools to brand Egypt online as a tourism destination.

Keywords: Destination Brand, Tourism Destination Website, Social Media, Tourism Applications, Egypt
\end{abstract}

\section{Introduction}

Using internet for travel services increases day by day which make tourism destinations, have to improve their marketing strategies online and moving to design an identity for their brands. One of the main factors that creates an attractive image for Tourism destinations are websites and mobile applications. Digital marketing now is contributing in raising destinations brand competitiveness (Anna et al., 2020). Online communication is considered one of the major bases of destination promotion. Destination Marketing Organizations (DMOs) use different communication channels to transfer brand messages (Trueman et al, 2004). Communication channels are ranging from traditional media such as brochures, newspapers, magazine ads and television commercials to the digital tools such as websites, social networks and mobile applications (Luna, \& Hyman, 2012). Egyptian tourist authority in Egypt has different online communication channels such as web-site, social media and mobile application. Little research has been analyzed the Egyptian official online channels. One of them was Chernysheva, et al, (2011) study analyzed the official tourism websites of 23 Mediterranean countries such as Spain, Cyprus, Turkey and Egypt. Their study used a content based on the slogans, graphic projections, verbal expressions and implied messages projected on the official countries ${ }^{\text {ee }}$ websites. They found that Egypt has a traditional melody of the country playing in the background, photos of desert and traditional buildings regarding to the appearance of the site. They demonstrated that the target segment of the website was for the Family vacations, fans of cultural diversities and sport events. They also found that the Egyptian official website promoted for Nature, archeological sites, Sports (golf), safari. A limited study has investigated the website evaluation and its importance of branding tourism destination (Dimitrovski et al., 2019: Marchiori et al., 2013). The study tried to analyze the features of the online channels and to what extent these channels are convenient to brand Egypt as a tourism destination. So, the aim of this study is divided in two objectives: Firstly, is to assess the features of the Egyptian online channels (Official Tourism Websites, the presence of the social media linked to the website and the presence of its mobile application. Secondly, is to evaluate the interactivity of the Egyptian online channels in communicating Egypt as a tourism destination brand. 


\section{Literature review \\ Destination branding}

Destination brand communicates expectations of what the destination will deliver in terms of products, services, and tourist/visitor/customer experience (Yavuz, 2016). Destination brand could be defined as "a deliberate strategy aiming to identify and differentiate a tourist destination from its competitors" (Sartori, Mottironi and Corigliano, 2012 P: 328). It can be broadly defined as: "the set of marketing activities that (1) support the creation of a name, symbol, logo, word mark or other graphic that readily identifies and differentiates a destination.; (2) the tools consistently convey the expectation of a memorable travel experience that is uniquely associated with the destination (Blain et al., 2005, p. 337; Kerr, 2006, p. 277). Destination brand could deliver an appealing tourist experience, which in turn has a positive effect on tourist satisfaction, brand trust and intention to re-visit (Barreto, et al, 2019).

\section{On-line channels for communicating destination brand}

Internet offers different opportunities for creating destination brands because the advantages of the internet exceed the traditional methods for promoting the destination brand and fulfilling customers' needs (Palmer, 2005). In the new era and the revolution of information, websites become the most important channel for communicating destination brands and promoting tourism and travel services (Fernández-Cavia \& Huertas, 2009; Díaz-Luque, 2009). Developing an official destination website is considered one of the challenges facing DMOs. The official website plays an important role in attracting potential tourists, providing them with different information and definitely building a destination brand. The website of a tourism destination could improve the online communication with users and play an important role to achieve a comprehensive destination stigmatization. Although, Morrison (2013) suggests that websites are the most important tool to communicate destination brand in DMO marketing strategy. But Morrison (2013) claims that (DMOs) have to develop and link their official websites to social networks, such as Facebook, Instagram, You-tube, Twitter, Pinterest, etc, to build and maintain customer relationships and to collect reliable content generated by the user. Standing, Tang-Taye and Boyer (2014) highlighted that tourism industry must use information and communication technologies intensively via Social media, mobile applications, photographs and videos sharing platforms. These are now powerful tools for building relations with potential visitors and communicating destination brands (Stepchenkova \& Zhan, 2013; Kahn, 2014; Kladou \& Mavragani, 2015).

\section{Official Destination website}

Official websites are considered important tools for providing information to tourists. The official website is a channel for marketing related services and products and a platform for sharing information and experiences (Díaz-Luque, 2009; Fernández Cavia \& Huertas-Roig, 2009). DMOs should improve their official websites for two reasons: (1) Internet users who represent the potential tourists believe such websites represent destinations, (2) It is an opportunity to evaluate tourism services offered by the destination (Kim, Shaw, \& Schneider, 2003). The usefulness of a destination Website is found in its design, content, navigation and accessibility (Kaplanidou \& Vog, 2006). Regarding the design, DMOs must focus on different factors such as functionality, usability, graphics, multimedia, layout and aesthetic features which leads to a successful website designing (Luna \& Hyman, 2012). Aesthetic features are 'visual items that can raise the interests of online travelers such as pictures, colors and graphical layout' (Han \& Mills, 2006, p. 414). The visual items are such as online video clips, logos and attraction photographs. These items may support information transfer such as brochures, destination-related backgrounds and slogans. and enhance visitors' experiences and website reliability (e.g. 
organized layout, site map, search tools and clear and readable text) (Luna \& Hyman, 2012). Tsai (2010) consider the content of government tourism websites is a very crucial tool for shaping the destination's culture, creating its image, promoting a tourist destination's cuisine and local food and creating a virtual experience for the potential tourist (Gretzel et al., 2000). A Web site's content can be defined as "the combination of functional information text and motivating visuals that encourage the user to plan a trip to the destination (Kaplanidou and Vog, 2006 P.206). Content could be texts, pictures, graphics, videos, and audios to promote the destination. Of course, text is the most effective communicating tool especially with the slow speed of Internet because it downloads faster than pictures or videos (Kaplanidou and Vog, 2006). To make the navigation experience useful for the visitor, the movement through the Web site's pages must be easy from the home page to any other pages (Evans and King 1999). Evans and King 1999 confirmed that the more the website is technically well supported, the more the user would be satisfied with the website. Accessibility for the website means how easy the user finds the website on the internet and the speed of download the homepage and subpages of the website. DMOs have to develop their websites within the principles of Search Engine Optimization (SEO) to raise exposure, information and ranking. SEO is the process to achieve the highest possible rank in the search results in a search engine using the suitable keywords to increase the number of visitors (Tolica, et al, 2017). Rincón, (2010) confirmed that DMOs have to set a strategy to integrate their websites into their destination's marketing plans and work on turning the official destination website into a successful communication channel. Developing successful websites has a great effect on saving cost in promotion, spreading out information in short time and enhancing destination's brand (Díaz Luque, 2009). Developing a successful website is not enough to guarantee the success of destination brand. Destination website has to match tourists' expectations, handle their information requests and meet their specific needs ((Palmer, 2005; Roney and Ozturan, 2006).

\section{Social Media}

The term Social media described as "a group of Internet-based applications that build on the ideological and technological foundations of Web 2.0 that allow the creation and exchange of user-generated content" (Kaplan \& Heinlein, 2010). One of the main characteristics of tourism industry is the intensive of information, whereas tourists could rely on social media to search for the information about destinations as well as bookings (Gretzel et al., 2000). Neti (2010), considered one of the most powerful and fastest means of branding social media. While Vijoli \& Marinescu, 2016 stated that (DMOs) could use social media create a powerful brand. Destination branding now has become a two-way communication due to social media. Consumers on social media share their experience on a brand and sometimes by posting their own videos or their words create a brand (Hipperson, 2010). Social media content provides the destination with an important platform for destination brand creation (Hays et al., 2012; (Kastenholz, et al, 2013).). There are various types of social networking sites are used for sharing content and are considered a new wave of web-based communities known as Web 2.0 (e.g. Facebook; Twitter; Instagram; You-tube, Trip advisor). These types have become new marketing tools for developing tourism destination destinations brands (Buhalis et al., 2011). Most Destination Management Organizations (DMOs) use the social media as a communication tool but many of them do not know how to manage it to reach their target markets (Huertas \& Marine-Roig, 2015). Sevin, (2013) concludes how using twitter by DMOs is beneficial and described how France gained connection with travel journalists by solely relying on Twitter. Hays et al., (2013) mentioned that Facebook is a more effective social networking site for DMOs. 


\section{Mobile applications}

Mobile devices are now playing an important role in promoting tourism and communication strategies. Mobile marketing has special features such as customization, interactivity and ease-ofuse (Alqatan et al., 2011; Scolari, \& Fernández-Cavia, 2014). In the last few years, smartphones are becoming the most important social media devices (Királ'ová \& Pavlíčeka, 2014). Especially, after the revolution of the new generation of smartphones and the emergence of the applications that must be downloaded from a specific platform (App Store, Google Play, etc.). The field of tourism mobile applications has a significant development such as city maps, urban mobility, specific tourist guides, augmented reality systems, etc. (Scolari \& Fernández-Cavia, 2014). However, tourism destinations must understand how the mobile applications could add a value to destinations band (Kenteris, et al., 2009; Karanasios, et al., 2012).

\section{Measuring the ability of on-line channels to promote destination brand}

Measuring Official Destination Website

Most of tourism website evaluation research tried to analyze the effectiveness of web site features such as navigation, content, and accessibility, interactivity, design and customer service (Ha \& Love 2005; Kline et al.,2004; Morrison et al., 2004). Litvin et al., 2008 considered that the evidence of an effective official tourism website design measured by the number of online visitors. Ho \& Lee (2007) proposed eight dimensions to evaluate travel \& tourism websites. Those are quality of information, security, ease of use, availability, customization, community, responsiveness and delivery fulfillment. Tanrisevdi \& Duran, (2011) mentioned that WTO in 2001, developed destination websites evaluation criteria with five main features: main page, user interface, information richness, interactive travel planners, virtual brochures, and site characteristics. Barreto \& Martínez, (2018) proposed nine dimensions for destination websites' evaluation from previous studies (Park et al., 2007; Tsang et al., 2010): (1) ease of use; (2) responsiveness; (3) fulfillment; (4) security/privacy; (5) personalization; (6) visuals; (7) quality of the information; (8) trust; and (9) interactivity. While, Dickinger and Stangl (2013) analyzed the tourism website performance by using similar dimensions (usability, user-friendliness, enjoyment, design, confidence, content quality, navigation and availability). Tang et al. (2012) analyzed destination websites using several sub-dimensions: web design (appearance, userfriendliness and functionality); and the quality of the information (relevance, usefulness and amount of information). Fernández-Cavia et al. (2014) and Fernández-Cavia \& Castro (2015) developed the Web Quality Index to measure the quality of destinations websites. The index consists of various indicators grouped under four areas of assessment: persuasive aspects, technical aspects, interactive aspects, and communication aspects. However, Loureiro (2015) proposed four dimensions to assess the quality of tourist destination website. The measurement dimensions were the visual appearance, information content, ease of use and interactive features. Anna et al., (2020) tried to assess the destination websites quality performance of Peloponnese in Greece. Their study used two main dimensions (content \& usability), in each dimension group of sub-dimensions in a set of 42 quality parameters to evaluate 51 websites.

Measuring social media channels

Measuring the effectiveness of the social media channels depends on three main dimensions (Pradiptarini, 2011): (1) its messages/contents quality, (2) the company's involvement, and (3) its association with the other marketing platforms. Pradiptarini, (2011) demonstrated that brand recognition will increase by combining social media with other marketing tools on the internet. Based on Pradiptarini's (2011) explanation Labbaika, (2015) set three conditions for social media activities in destination branding: Good quality of social media content, Involvement from the whole DMO and Integration with other marketing activities. 


\section{Measuring tourism applications}

Stienmetz et al., (2012) stated that these days mobile marketing influence on destination branding is increasing. Recently, there is a clear interest in evaluating mobile applications and the services that they offered to tourists (Hyun et al, 2009). Significant studies tried to focus on mobile etourist guides or app-based mobile tour guides and investigated their support for maps or mobility issues (Eisenhauer, et al, 2003; Mak et al, 2015). Grün et al, (2008) developed a framework to evaluate mobile tourist guides services offered to tourists during their trip based on three dimensions: service delivery, service initiation and service customization. Karanasios, et al. (2011) proposed a framework for evaluating mobile tourism applications adapted from Kenteris (2009) and Grün, et al. (2008). The framework is based on four dimensions: service delivery (information, transaction or community), customization (context or adaptation), initiation (push or pull) and application type (pre-installed-live, pre-installed-static or web based) (Scolari \& Fernández-Cavia, 2014). Fernández-Cavia \& López (2013) developed a model to analyze Spanish destination mobile applications for destination branding. The model includes several indicators under eight variables: Genre refers to the application type. Origin refers to the mobile applications content whether it is developed or adapted. Function refers to the main uses of the mobile application. Link structure, indicates that the application considered as centrifugal which means that the user could deprive from the application to see destination attributes. Or the application considered as centripetal which means the application keeps the user in rather than moving them outside the application. Spaces refer to the setting of the application weather that provides information or encourages interaction between users or between the user and the destination. The Model author seeks to identify the application created by official tourist organizations. The Model user looks at to weather the application addressee to the tourist or to the local citizens or both of them. Usability analyses the ease, security and convenience of the mobile application. Scolari, \& Fernández-Cavia, (2014) study evaluated 66 applications of the official Spanish tourism destinations websites characteristics concerning their role in destination branding.

\section{Methodology}

The first objective of the study is to assess the Official Egyptian Tourism Websites features, the presence of its social media tools and the features of the mobile application downloaded from the website. The second is to evaluate the interactivity of the Egyptian online channels in communicating Egypt as a tourism destination brand. The study used the content analysis to evaluate the official tourism website. This method has been used to evaluate websites in tourism and hospitality studies by different researchers (Anna et al., 2020; Gupta \& Utkarsh. 2014; Han and Mills 2006; Morrison et al. 2004). Some researchers have used web content analysis to measure the frequency of certain images or text on a tourism website (Govers and Go, 2004). Other researchers have used web content analysis by conducting specific models based on previous studies (Mavridis, and Symeonidis, 2014). Applying content analysis provides researchers with many opportunities in particular, analyzing the complexity of mixed media (text, graphics, animation, video and audio etc), interactivity and hyperlinked structures (Kim \& Kuljis, 2010; Neuendorf, 2002). In this study, content analysis was carried out by tracking the presence or absence of the elements of three analysis models. The first model was to assess the perceived features of the Egyptian official tourism and the presence of its social media tools. The second was to evaluate the interactivity of the Egyptian official tourism website and its social media regarding their ability to brand Egypt as a tourism destination. The third was to assess the characteristics of the tourism mobile application linked by the official website in relation to brand Egypt. The assessment process involved three assessors to guarantee neutrality and avoid 
mistakes. The process was carried out by one of the professionals in digital marketing, a web analyst and the author.

\section{Method}

There are no formal metrics for assessing destination website features. Previous researchers investigated different attributes of websites from different scopes (Luna \& Hyman, 2012). The study used Luna \& Hyman, (2012) analysis model for assessing destination website features. This model evaluated the official tourism websites of 262 top global destinations (including Egypt) by number of international arrivals in 2008. Luna \& Hyman, (2012) used a list of destinations was obtained from the 2009 edition of Euromonitor International's Top City Destination Ranking. The authors considered the destination website homepage (the first page presented when entering a website) is the unit of analysis. Luna \& Hyman, (2012) developed a codebook with 26 variables that fall into six broad categories as presented in table 1 . These categories are (1) Primary focus that includes one variable: primary focus which presented in three types (predominantly informative, predominantly commercial, or informative-commercial). (2) Visual and presentation style which includes nine variables (Page size, Page layout, Number of images, Destination brand shown, animated images, animated buttons/links, Pop-up window, stream audio/music and Stream video). (3) Navigation and interactivity which includes four variables (site map, search tool, languages other than local and level of interactivity). (4) Textual information which includes three variables (homepage title, number of keywords in title and text length). (5) Advertising which includes four variables (number of banner ads, animated ad, ad product type and main ad size). (6) Social media and travel aids which includes five variables (social media tools, city map, weather information, calendar of events and hotel booking service). Luna \& Hyman, (2012) divided the websites to three clusters. Cluster 1 is characterized by a modern and highly attractive design, informative-commercial, present a homepage with little verbal information and aesthetics-oriented. The aesthetics orientation is evidenced by the high number of images, the presence of animation in buttons and images, the moderate use of banner ads and the presence of social media tools, especially Facebook, Twitter, and You tube. Cluster 2 is characterized by simplistic, moderately commercial, information-oriented websites. It is evidenced by a high number of images but fewer animated images, buttons, and videos, small number of homepages include banner ads and lower social media usage rate. Cluster 3 is characterized by commercial high details, trans-action-oriented websites. These websites are displaying high emphasis on advertising, informative-commercial, transactional features, and their homepage always includes at least one banner ad. Cluster 3 websites rely on high details structure and a high social media usage rate.

Table 1: Codebook of Luna-Nevarez and Hyman (2012)

\begin{tabular}{|l|c|}
\hline Measured variable & Value \\
\hline 1-Primary focus & 1 \\
\hline Predominantly informative/cultural & 2 \\
\hline Predominantly commercial/transactional & 3 \\
\hline Informative-commercial & \\
\hline 2-Visual and presentation style & 1 \\
\hline Page size & 2 \\
\hline Small (1-2 screens) & \\
Large (3 or more screens) & 0 \\
\hline Page layout & 1 \\
\hline Unbalanced & \\
Balanced & \\
\hline
\end{tabular}




\begin{tabular}{|c|c|}
\hline Measured variable & Value \\
\hline \multicolumn{2}{|l|}{ Number of images } \\
\hline Few images & 1 \\
\hline Many images & 2 \\
\hline \multicolumn{2}{|l|}{ Presence of } \\
\hline Destination brand shown (Logo) & $0-1$ \\
\hline Animated images (slide show) & $0-1$ \\
\hline Animated buttons (links) & $0-1$ \\
\hline Pop-up images & $0-1$ \\
\hline Stream Audio & $0-1$ \\
\hline Stream Video & $0-1$ \\
\hline \multicolumn{2}{|l|}{ 3-Navigation and interactivity } \\
\hline \multicolumn{2}{|l|}{ A-Presence of } \\
\hline Site map & $0-1$ \\
\hline Search tool & $0-1$ \\
\hline Languages other than local (Multiple languages offered) & $\begin{array}{c}\text { Same (Multiple languages offered } \\
\text { or one foreign language) }\end{array}$ \\
\hline \multicolumn{2}{|l|}{ B-Level of interactivity } \\
\hline Small (main menu with 0-5 links) & 1 \\
\hline Medium (main menu with 6-10 links) & 2 \\
\hline High (main menu with more than 10 links) & 3 \\
\hline \multicolumn{2}{|l|}{ 4-Textual information } \\
\hline \multicolumn{2}{|l|}{ Presence of } \\
\hline $\begin{array}{l}\text { Homepage title } \\
\text { Number of keywords in title }\end{array}$ & $\begin{array}{c}\text { Same (weather contain little text } \\
\text { or long) }\end{array}$ \\
\hline & $\begin{array}{c}\text { Same (Number of keywords in } \\
\text { destination title suggested in } \\
\text { search engines) }\end{array}$ \\
\hline \multicolumn{2}{|l|}{\begin{tabular}{|l|} 
Text length \\
\end{tabular}} \\
\hline Few words & 1 \\
\hline Many words & 2 \\
\hline \multicolumn{2}{|l|}{ 5-Advertising } \\
\hline Number of banner ads (at least one ad) & Same (Weather one ad or more) \\
\hline \multicolumn{2}{|l|}{ Animated ad } \\
\hline Absence of animated ads & 0 \\
\hline Presence of animated ads & 1 \\
\hline \multicolumn{2}{|l|}{ Ad Product type } \\
\hline Non-tourism related & 0 \\
\hline Tourism related & 1 \\
\hline \multicolumn{2}{|l|}{ Main ad size } \\
\hline Small (r1/8th screen) & 1 \\
\hline Large (41/8th screen) & 2 \\
\hline \multicolumn{2}{|l|}{ 6-Social media and travel aids } \\
\hline \multicolumn{2}{|l|}{ Presence of } \\
\hline Social media tools & $0-1$ \\
\hline City map & $0-1$ \\
\hline Weather information & $0-1$ \\
\hline Calendar of events & $0-1$ \\
\hline Hotel booking service & $0-1$ \\
\hline
\end{tabular}


The study adopted the Web Quality Index developed by Fernández-Cavia et al., (2014). This model has been developed based on the recommendations of the WTO. The model based on four areas of assessment focuses on twelve parameters assessed using 123 indicators. The Four areas were technical aspects, communicative aspects, relational aspects and persuasive aspects. The study focused on two parameters in relational aspects interactivity and social media. The study through the model tried to assess the interactivity of the Official Egyptian Tourism Website, the social media tools linked by the website and its mobile application in communicating online tourism brand. Interactivity is considered one of the most important features of websites for branding because it helps users to navigate searching for the brand (Macias, 2010). Social media are known as the new channels for communicating brands (Sigala, 2009; Xiang and Gretzel, 2010). Table 2. illustrates using the third area of assessment (relational aspects) in FernándezCavia et al (2014) model. (1) Interactivity (I) which includes 12 indicators. These indicators are forming 3 types of interaction identified by Cho and Cheon (2005). User-message interaction contains six indicators in the websites (I1-I6); user-user interaction contains two indicators (I7I8); user-administrator interaction contains three indicators (I9-I12). (2) Social media on the web (SW) which includes 8 indicators. These indicators are forming 2 types of social media identified by Míguez-González, and Fernández-Cavia (2015). The use, tools and functionalities of the social web (SW1-SW6) and the use of social networks and external recommendation networks (SW7-SW8).

Table 2: The analysis model of Fernández-Cavia et al. (2014)

\begin{tabular}{|c|c|c|c|}
\hline $\begin{array}{c}\text { Areas of } \\
\text { assessment }\end{array}$ & Parameters & Description & Indicators \\
\hline \multirow{5}{*}{ 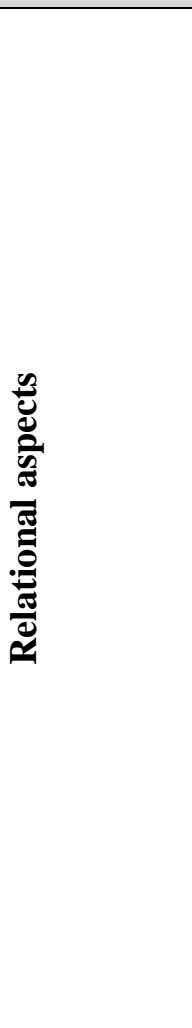 } & \multirow{5}{*}{$\begin{array}{l}\text { Interactivity } \\
\text { (I) } \\
(12 \\
\text { Indicators })\end{array}$} & \multirow{5}{*}{$\begin{array}{l}\text { User-message interaction } \\
\text { (6 Indicators) }\end{array}$} & $\begin{array}{l}\text { I1. Multimedia display } \\
\text { Without multimedia } \\
\text { Display } \\
\text { Static camera } \\
\text { Virtual tour }\end{array}$ \\
\hline & & & $\begin{array}{l}\text { I2. Video } \\
\text { No video } \\
\text { Outsourced videos } \\
\text { Integrated video } \\
\text { Integrated interactive } \\
\text { Video }\end{array}$ \\
\hline & & & $\begin{array}{l}\text { I3. Downloads } \\
\text { No downloads } \\
\text { Few downloads or payment downloads } \\
\text { Free downloads }\end{array}$ \\
\hline & & & $\begin{array}{l}\text { I4. Mobile applications } \\
\text { No downloads } \\
\text { Free downloads }\end{array}$ \\
\hline & & & $\begin{array}{l}\text { I5. Interactive resources (e.g such as interactive } \\
\text { maps, games or online music) } \\
0-1 \\
2-4 \\
>4\end{array}$ \\
\hline
\end{tabular}




\begin{tabular}{|c|c|c|}
\hline & & $\begin{array}{l}\text { I6. Trip planner } \\
\text { No } \\
\text { Itinerary } \\
\text { Trip planner with information from the web } \\
\text { Trip planner with user information }\end{array}$ \\
\hline & \multirow{2}{*}{$\begin{array}{c}\text { User-user } \\
\text { Interaction } \\
\text { (2 Indicators) } \\
\end{array}$} & $\begin{array}{l}\text { I7. Clubs, communities or groups of users from } \\
\text { the destination }\end{array}$ \\
\hline & & I8. Travel stories, experiences, or summaries \\
\hline & \multirow{4}{*}{$\begin{array}{l}\text { User-administrator } \\
\text { interaction } \\
\text { (4 Indicators) }\end{array}$} & $\begin{array}{l}\text { I9. Potential to comment created by the } \\
\text { destination on textual, photographic and video } \\
\text { content }\end{array}$ \\
\hline & & I10.Ability to vote on content \\
\hline & & I11.Scope for user-generated content \\
\hline & & I12.Chat line or human click. \\
\hline \multirow{8}{*}{$\begin{array}{l}\text { The social } \\
\text { web }(\mathrm{SW}) \\
\quad(8 \\
\text { Indicators) }\end{array}$} & \multirow{6}{*}{$\begin{array}{l}\text { The use, tools and } \\
\text { functionalities }\end{array}$} & SW1.Website allows for user-subscription \\
\hline & & SW2.Website allows users to share information \\
\hline & & SW3: A corporate blog associated with the web \\
\hline & & $\begin{array}{l}\text { SW4: Destination uses micro-blogging } \\
\text { platforms }\end{array}$ \\
\hline & & $\begin{array}{l}\text { SW5.Website uses image platforms like Flickr, } \\
\text { Picassa or Instagram. }\end{array}$ \\
\hline & & $\begin{array}{l}\begin{array}{l}\text { SW6.Website uses } \\
\text { YouTube. }\end{array} \\
\text { Yideo platforms like } \\
\end{array}$ \\
\hline & \multirow{2}{*}{$\begin{array}{l}\text { The use of social networks } \\
\text { and external } \\
\text { recommendation networks }\end{array}$} & SW7. A Facebook page associated with the web \\
\hline & & $\begin{array}{l}\text { SW8: Website uses external recommendation } \\
\text { social networks like Trip advisor }\end{array}$ \\
\hline
\end{tabular}

In order to analyze features and the interactivity of the mobile application linked by the Egyptian official website, the study adopted Scolari, \& Fernández-Cavia, (2014) model with its five variables. They developed their model to evaluate tourism mobile applications based on previous studies (Fernández-Cavia et al. 2014; Fernández-Cavia \& López, 2013; Scolari et al, 2012). The model identified general properties that must be founded in the applications (i.e. business model, number of languages, Hyper-textual connections, Content, presence of social networks and usergenerated content).

Table 3: Scolari, \& Fernández-Cavia, (2014) analysis model for mobile application

\begin{tabular}{|c|c|}
\hline Measured variable & Its indicator \\
\hline \multicolumn{2}{|c|}{ (1) Business model and production } \\
\hline \multirow[t]{3}{*}{ Business model } & Free \\
\hline & Pay \\
\hline & $\begin{array}{l}\text { Freemium (For free, but money was charged for } \\
\text { advanced features) }\end{array}$ \\
\hline \multirow[t]{3}{*}{ Production } & Unofficial applications produced internal \\
\hline & Unofficial applications produced external \\
\hline & Official applications produced external \\
\hline \multicolumn{2}{|l|}{ (2) Language } \\
\hline & 1 \\
\hline & 2 \\
\hline & 3 \\
\hline & 4 or + \\
\hline \multicolumn{2}{|l|}{ (3) Hypertextual connections } \\
\hline
\end{tabular}




\begin{tabular}{|c|c|}
\hline Measured variable & Its indicator \\
\hline & Web-application link \\
\hline & No link \\
\hline \multicolumn{2}{|l|}{ (4) Content } \\
\hline \multirow[t]{2}{*}{ Origin of the content } & Adapted \\
\hline & Original \\
\hline \multirow[t]{9}{*}{ Functions } & Resources at the destination \\
\hline & Geo-location \\
\hline & Agenda \\
\hline & Augmented reality (AR) \\
\hline & Photo gallery \\
\hline & Comments \\
\hline & Audio guide \\
\hline & Promotions \\
\hline & Video guide \\
\hline \multirow[t]{2}{*}{ Identification } & Easy identification \\
\hline & Logo visible \\
\hline \multirow{3}{*}{ Quality of content } & No info \\
\hline & Low quality \\
\hline & High quality \\
\hline \multicolumn{2}{|c|}{ (5) Social networks and user-generated content } \\
\hline & Facebook \\
\hline & Twitter \\
\hline & YouTube \\
\hline & Trip advisor \\
\hline & Pinterest \\
\hline & Instagram \\
\hline & Flickr \\
\hline
\end{tabular}

Table 3. Presents the five variables of mobile application and its indicators: (1) Business model and production: The tourism applications might be free or paid or Freemium which means the application is provided for free but money will be charged for extra features. Regarding to the production the tourism applications might be unofficial which means it produced by external companies. It might be unofficial which means it produced by individuals. It might be official applications commissioned by public agencies and most of the DMOs adopt this application. (2) Language: It is an important issue in tourism applications because translation gives the researcher more information about the official tourism destination. (3) Hyper-textual connections: The consistency or the connection between the application and the webpage strategies. It means it must be a hyper-textual link between the official tourism webpage and the application download. Another trait of the hyper-textual structure is the application includes links to external websites (centrifugal) or links to the application itself (centripetal) (4) Content: Mobile application must include aspects like origins, functions, identification and quality. (a) Origin of the application has two classifications: applications with original content and applications adapted from the official tourism website). (b) The functions could be: geo-location services, photo gallery, agenda, destination resources, augmented reality (AR), and the possibility of sharing comments. (c) Identification: It means how the user identifies the name and logo of the application comes from and its signs to promote for the destination brand. (d) Content quality: the quality of the content of the applications might be in three categories. No information means the application does not include a map or information about the history of the destination. Low quality information means 
the application includes a map but not interactive and the history information is not complete or organized. High quality information means the application includes an interactive map and has complete information, photos, and dates of the history of the destination. (5) Social networks and user-generated content: user-generated content: The email function is considered a social network to share content but the most important is to include a link to a Facebook page and Twitter. The application must offer online space for sharing pictures, personal messages, hotel evaluations and restaurant recommendations.

\section{Sample}

The first step was to identify the official websites of the national tourism organization (NTO) in Egypt. The data were analyzed from the Egyptian Tourism Authority website (ETA) and the Egyptian Ministry of Tourism and Antiquities website (MOA) http://egypt.travel/, https://egymonuments.gov.eg/en The social media presence based on the hyperlinks provided in the websites to determine the dominant social media platform used by the official tourism websites. Analyzing the integration between the social media and the official destination is to identify the social media presence based on the hyperlinks provided in the websites. Facebook page:

https://www.facebook.com/eg.ExperienceEgypt/?brand_redir=159349944083305, https://www.facebook.com/moantiquities/

Twitter account: https://twitter.com/ExperienceEgypt, https://twitter.com/egymonuments?s=04 You-tube channel: https://www.youtube.com/channel/UCbEsrYwtICShIo_VPoBCQGw, https://www.youtube.com/channel/UCxJmhXT-FbB10quBphLvJDQ

Instagram account: https://www.instagram.com/experienceegypt/ for the Egyptian Tourism Authority only

Identifying the Mobile application downloaded from the platforms (App Store, Google Play) linked by the Egyptian tourism website.

\section{Results}

The analysis focuses on measuring the features and the interactivity of the websites, its social media and its mobile application. The study used three models, the first based on six parameters for assessment to determine the destination websites features and the presence of the social web. In the second model, the study used only the 20 indicators of the third area of assessment (relational aspects) to evaluate the interactivity of the website and its social media tools. The study used the third model to evaluate the characteristics of the mobile application and its interactivity. These results are explained by the content analysis technique to emphasize the presence of the website, social web and mobile application features and interactivity, as indicated by Luna \& Hyman (2012); Fernández-Cavia et al. (2014) and Scolari, \& Fernández-Cavia, (2014).

\section{Destination website features and the presence of its social web}

Using the model analysis of Luna \& Hyman, (2012) indicators showed that the results of assessing the Egyptian websites features regarding to the primary focus that the website is predominantly informative. It targets users seeking information and ignoring shoppers seeking epurchases. For visual and presentation style, the web page size is large ( 3 or more screens), page layout is balanced, more than 5 images, the destination logo brand is shown, image slide is shown, pop-up window is shown and there is an audio and a video Streaming. Regarding Navigation and interactivity, there is a site map, a search tool, multiple languages offered and medium level of interactivity (main menu with 7 links). For textual information, there is no homepage title and there is not any type of advertising or banner ads. For the presence of social media and travel aids, there are Facebook, twitter and you-tube for both websites. For the 
Egyptian Tourism Authority Instagram and although Google+ is no longer available the icon of this platform is still on the webpage of. There are also a destination map and Weather information. There is no calendar or any type of booking services. This means the Egyptian official websites are in Cluster 2 of Luna \& Hyman, (2012) model. They are characterized by simplistic, moderately commercial, information-oriented websites. Table 4. summarizes the attributes of the Egyptian official website.

Table 4: The attributes of the Egyptian official websites based on Luna-Nevarez and Hyman model (2012)

\begin{tabular}{|c|c|c|}
\hline Measured variable & Category & Value \\
\hline \multicolumn{3}{|l|}{ 1-Primary focus } \\
\hline Primary focus (Foc) & $\begin{array}{l}\text { Predominantly informative/cultural (cultural aspects, } \\
\text { places to visit, local news, Weather, travel planning) }\end{array}$ & 1 \\
\hline \multicolumn{3}{|l|}{ 2-Visual and presentation style } \\
\hline $\begin{array}{l}\text { Page size (based on } 1024 \times 768 \text { screen } \\
\text { resolution) }\end{array}$ & Large (3 or more screens) & 2 \\
\hline Page layout (Lay) & Balanced & 1 \\
\hline Number of images (Img) & Many images (5 images) & 2 \\
\hline Destination brand shown (Log) & Logo & 1 \\
\hline Animated images (Ani) & Image slide show & 1 \\
\hline Pop-up window (Pop) & Pop-up window(s) & 1 \\
\hline Stream audio/music (Aud) & Audio & 1 \\
\hline Stream video $(\mathrm{Vid})$ & Video & 1 \\
\hline \multicolumn{3}{|l|}{ 3-Navigation and interactivity } \\
\hline Site map (Map) & Site map & 1 \\
\hline Search tool (Set) & Search tool & 1 \\
\hline Languages other than local (Lan) & Multiple languages offered & Same \\
\hline Level of interactivity (Int) & Medium (main menu with 7 links) & 2 \\
\hline \multicolumn{3}{|l|}{ 4-Textual information } \\
\hline Homepage title (Tit) & & No \\
\hline \multicolumn{3}{|l|}{ 5-Advertising } \\
\hline Number of banner ads (Adn) & & No \\
\hline \multicolumn{3}{|l|}{ 6-Social media and travel aids } \\
\hline \multirow[t]{4}{*}{ Social media } & Facebook (FB) & 1 \\
\hline & Twitter (TW) & 1 \\
\hline & You-tube (YT) & 1 \\
\hline & Instagram & 1 \\
\hline City map (Cmp) & City/destination map & 1 \\
\hline Weather information (Wea) & Weather information & 1 \\
\hline Calendar of events (Cal) & No calendar & 0 \\
\hline Hotel booking service (Bok) & No booking services & 0 \\
\hline
\end{tabular}

\section{The interactivity of the destination website and the social medial tools linked by the website}

Using the analysis model developed by Fernández-Cavia et al. (2014) in relation to the interactivity and social web tools indicators. The results of indicators linked to user-message interaction analysis were sufficient, the official websites allow the user to go on a virtual tour. Only the ETA website has a promotional video of Egypt, which can be easily identified on the homepage. The website provides integrated interactive videos. However, both websites offer the user a reasonable volume of free information, but only ETA website offers free downloads for the videos and the mobile application is downloading free. Both websites do not offer alternative interactive resources; it only offers an interactive road map with information for different 
attractions in Egypt. ETA website includes a trip planner with information from the web. Analyzing the indicators of user-user interaction are not quite good, the websites have no user communities such as a Facebook group or a window on the website allowing users to direct access of these groups. Both websites provide stories and experiences but does not provide travel summaries. Analyzing user-administrator interaction indicators were not satisfied. ETA website allows users to comment on textual, photographic and video content created by the official website, but both websites do not permit users to vote on content. ETA website allows for usergenerated content to be published on the website. Lastly, both websites do not have a chat line. In general, six indicators were verified out of 12. In relation to the presence of the social web (SW) the results of indicators were not satisfying. For the use, tools and functionalities, the websites do not allow for user-subscription to content syndication services or to share information of their interest. The websites do not include a corporate blog associated with the web domain. The websites only use micro-blogging platforms such as twitter. ETA website uses image platforms such as Instagram (for MOA, Instagram is not activated). Both websites use video platforms like YouTube. For The use of social networks and external recommendation networks, the websites have Facebook pages associated with the web domain but not highly used. The use of external social recommendation networks is not common for official websites. In conclusion, four indicators of eight were verified.

The characteristics and the interactivity of the tourism mobile application downloaded from the ETA website

The results of using Scolari, \& Fernández-Cavia, (2014) model analysis revealed the following. In general, Egyptian tourism application is free-of charge, developed by external agency. The language of the application is in Arabic, English, French, German, Italian and Russian. The application is connected to the Egyptian official tourism websites, but the user could download any attraction to save it on the phone to view it offline. The content of the application is adapted from the official tourism website. Regarding the functions proposed by the mobile interfaces, the study identified a photo gallery, 3D attractions, selfie, 360 view, QR scan and events calendar. The Egyptian application does not include sharing comments, augmented reality, geo-location or weather information. The application displays all the attractions around Egypt that are presented on the website. These attractions grouped under seven categories (Relaxation, culture, family, adventure, romance, spirituality and others). The interface of the application focused on the top ten attractions are visited in Egypt (such as Dolphin House, Shop for dates, Ras Um Sid, Valley of the Kings etc). There is an obvious lack of content quality, the application does not include (maps), transport information (buses, trains, airports, etc.), accommodation (hotels, campsites, etc.), visits (museums, monuments, etc.), agenda (exhibitions, cultural events, etc.). The application is limited with history and features of the place, cultural habits and weather. Regarding identification (naming and logotypes) the user could immediately identify where the application comes from (the name and the logo is clear). The Egyptian application does not include any of the user-generated content.

\section{Discussion and conclusions}

The study tried to examine the online communication channels of the National Egyptian Tourist organizations in terms of the features and interactivity. The study focused on the Egyptian Tourism Authority website and the Egyptian Ministry of Tourism and Antiquities websites, the social media tools linked by and Egyptian tourism application representing the official Tourist organization. Regarding the features of the Egyptian official websites, the analysis showed that the websites have a balanced design, seven screens for ETA/ six screens for MOA, and includes multiple high-quality pictures that enhance many of the attributes of the Egyptian Tourism 
Attractions. These results are consistent with Luna-Nevarez and Hyman study (2012) who emphasize that using graphics more than text content, especially the animated images (e.g. image slideshows) showing the most distinguished attractions in the destination could create an attractive destination website. The main menus of homepage contain seven links for ETA and nine links for MOA, every link has sub-links grouped into fewer categories with descriptive names presented in an appealing design characterized by small pages and limited text. Search tools and language translation facilitate information-seeking effort and time by website users. English, Arabic, German, Spanish, French, Italian, Polish Chinese, Magyar, Danish, Netherland Russian, Czech and Japanese are the used languages on ETA website. While the MOA website uses only Arabic and English languages. Both websites have more graphics and less text on its homepage, this could create a good first impression for the visitors of the website. Both websites include interactive map, local weather information, and upcoming events. The ETA website is using a promotional video about Egypt produced by Trip advisor. The ETA website presents some stories of Egyptian visitors' experiences at different attractions in Egypt. Facebook, Twitter, YouTube and Instagram are related to the Egyptian websites as promotional tools. Both website do not include any blogs. The ETA has no title, but the MOA has a title while both websites do not use advertising or banner ads. Both websites also do not include any booking services. Regarding the interactivity, user-message interaction is the most clearly aspect. ETA website offers tools like interactive maps, trip planners, mobile application and multimedia display elements unlike the MOA has not. Concerning user-user interaction, some experiences are shared on both websites. Although, Yavuz, (2016) emphasized the importance of storytelling as a tool for destination branding, there is no place for word of mouth via communities or storytelling from visitors. User-administrator interaction is poor in both Egyptian websites because they do not offer the basic service of making comments on or voting for content. Regarding the interactivity of the social media tools linked by the official Destination Websites to evaluate their ability to brand Egypt online. Both websites allow users to use the most common social media tools like Facebook, Twitter, image platforms like Instagram and video platforms like YouTube. Visitors could easily access to the social media icons on the websites which open in new windows. Unfortunately, both websites have not had a corporate blog and the use of external recommendation networks in the website does not exist like the presence of Trip advisor. In addition, while the content of the Facebook page and you-tube channels for MOA website are up-graded unlike the Facebook page and you-tube channels for ETA website is not from a long time. Twitter and Instagram accounts are upgraded constantly for ETA, while only twitter account for MOA is active. Regarding the characteristics and the interactivity of the Egyptian tourism application. Although, Scolari, \& Fernández-Cavia, (2014) consider the usergenerated content one of the main components of the branding strategy. The Egyptian tourism application is missing the email function which is considered the last option for sharing content among users. Users of application have to plan and share their trips on the app. In spite of the fact that Egyptian application is using the latest technology such as 3D attractions, 360 view and QR scan but the lack of content quality could be a challenge to tourism branding. The application is addressing the tourist who visits Egypt for leisure, however, the application should include elements that attract visitor are coming for business and the applications must consider the generating of content by tourists.

The evaluation of the branding activities of the online channels of the Egyptian national tourism organizations proved that they have to reconsider their online promotion strategies. The study affirmed that the official tourism websites as the most important communication channels have to change the existing online efforts in order to promote Egypt as a destination brand. The Egyptian 
official websitse should place travel aids such as shopping, weather forecasts, night life, calendar of events and event tickets. The websites could use advertisements, but they must be related to tourism and travel products such as travel packages, hotels and car rentals. Destinations websites sometimes include advertisements for non-travel products or services. The ETA website must have a title represents the website's content. Truly the ETA website uses multiple languages but the most important to see the text of the website in search engines list results in local languages for penetrating international markets. The slogan has to promote the country's tourism products and services. The graphic and the verbal images must be consistent with the slogan because the graphical/verbal imagery is highly likely to project an attractive brand image. The Egyptian official tourism websites must provide tourists with the transaction function which allows them to shop electronically through the website to generate revenue for Tourism industry in Egypt. Increasing tourism information on the websites and its quality content could improve the user's attitude and extend the website effectiveness. Integration with the different marketing efforts is a necessary condition for an effective use of social media in destination branding. All online marketing platforms of the destination from social media to website must be at the same quality content level. Facebook, Twitter, YouTube and Instagram which are representing both ETA and MOA websites are not at the same interactivity. Although all the social media channels related to ETA or MOA websites under the same slogan" experience Egypt" / "Discover Egypt's Monuments" but not all the channels are upgraded and active.

\section{Implications, limitations and future research Managerial implications}

Destination management should first guarantee the policies that create a positive experience, favorable navigation and good reaction towards the website for users. Destination management also should implement a flexible marketing policy to enable integration between the different platforms for users to be more willing to visit the destination and recommend it for others. Destination management must develop online positioning strategies based on the type of targeted markets. National tourism marketing organization must find out which platform would be more effective for that targeted market and what kind of search engines do they prefer. Also, the upgrade of the website is necessary in order to become more competitive and more attractive in the international market whether in the content or the design of the website. Using narratives from tourists about their tourist experiences about famous tourist attractions could attract not only the new visitors but also the previous visitors. The visitors who have already visited the destination could learn something new about the destination from the experiences of these narratives. Increasing high interactive methods such as images, videos, and applications simulating virtual visits to the destination could generate high intention to visit and more recommendations for the destination. For the tourism application, it should be improved both on the level of navigation and attractiveness. Destination management could encourage users to cocreate online content on the social media tools with their postings and accordingly they could cobrand destinations by these practices especially on social media. Destination management could also implement planning the whole trip from booking to payment through the official website to make the experience more appealing and tangible. In general, tourism organizations could benefit from this research by using the analysis models to evaluate their website performance and also their competitor's websites.

\section{Limitations and future research}

The study used the content analysis as a method of analysis. The future studies could include focus groups, interviews and questionnaire with the potential users who visit the Egyptian 
official tourism websites. The study did not assess the reactions of website users because it analyzed only the content of the website and its homepage and its ability for branding Egypt. The study was limited to Facebook, Twitter, YouTube and Instagram since they are the most common social media platforms. The other types such as Trip advisor and Booking were not involved in this research, which also notably influence tourists' preferences. In addition, the study did not analyze the other official tourist bodies' website. In the future, other links related to the website must be analyzed. For social media, studies have to assess the effect of every tool separately. For future research, the researchers must study the users of different cultures which could be the starting point for increasing tourism destinations attractiveness.

\section{References}

Alqatan, S., Singh D., and Ahmad K. (2011). A Theoretic Discussion of Tourism M-commerce. Journal of Convergence Information Technology, 6 (12), 100-106.

Baggio, R. (2003). A website analysis of European tourism organizations, Anatolia. International Journal of Tourism and Hospitality Research, 14(2), 93-106.

Barreto, J.J., Rubio, N., and Martínez, S.C. (2019). The online destination brand experience: Development of a sensorial-cognitive-conative model, International Journal of Tourism Research, 21(2), 245-258.

Blain, C., Levy, S.E., and Ritchie, J.R.B. (2005). Destination branding: Insights and practices from destination management organizations. Journal of Travel Research, 43(4), 328-338.

Buhalis, D., Leung, D., and Law, R. (2011). E-Tourism: Critical Information and Communication Technologies for Tourism Destinations. In Wang, Y. \& Pizam, A. (eds.), Destination Marketing and Management, Theories and Applications, 205-224. Cambridge: CAB International.

Chernysheva, E., Skourtis, G. Assiouras, I. and Koniordos, M. (2011). An analysis of brandbuilding elements in the Official Mediterranean Tourism Websites. A Paper presented in the 40th EMAC Annual Conference, Ljubljana, Slovenia, 24-27 May.

Cho, C., and Cheon, H. J. (2005). Cross-cultural comparisons of interactivity on corporate websites: the United States, the United Kingdom, Japan, and South Korea. Journal of Advertising, 34(2), 99-115.

Díaz-Luque, P. (2009). Official Tourism Web Sites and City Marketing in Gascó-Hernández, M., \& Torres-Coronas, T. (eds.), Information Communication Technologies and City Marketing, Digital Opportunities for Cities around the World, 152-183.

Dickinger, A., and Stangl, B. (2013). Website performance and behavioral consequences: a formative measurement approach. Journal of Business Research, 66(6), 771-777.

Dimitrovski, D., Joukes, V., Rachão, S. and Tibério, M.L. (2019). Wine tourism apps as wine destination branding instruments: content and functionality analysis. Journal of Hospitality and Tourism Technology. 10 (2), 136-152.

Eisenhauer, M., Oppermann, R., and Schmidt-Belz, B. (2003). Mobile information systems for all. A Paper presented at the Proceedings of the Tenth International Conference on HumanComputer Interaction, 22-27 June.

Evans, J. R., \& King, V. E. (1999). Business-to-Business Marketing and the World Wide Web: Planning Managing and Assessing Web Sites. Industrial Marketing Management, 28, 343-58.

Fernández-Cavia, J. and Huertas-Roig, A. (2009). City Brands and their Communication through Web Sites: Identification of Problems and Proposals for Improvement. In Gascó-Hernández, M., \& Torres Coronas, T. (eds.), Information Communication Technologies and City Marketing. Digital Opportunities for Cities around the World. 
Fernández-Cavia, J., and López, M. (2013). Communication, destination brands and mobile applications. Communication \& Society, 26 (2), 95-113.

Fernández-Cavia, J., Rovira, C., Díaz-Luque, P., and Cavaller, V. (2014). Web Quality Index (WQI) for official destination websites. Proposal for an assessment system, Tourism Management Perspectives, 9(1), 5-13.

Fernández-Cavia, J., and Castro, D. (2015). Communication and branding on national tourism websites. Cuadernos.info., 37(1), 167-185.

Fernández-Cavia, J., Marchiori, E., Tang, C.H., \& Cantoni, L. (2016). Online communication in Spanish destination marketing organizations: The view of practitioners. Journal of vacation marketing, 23(3), 264-273.

Govers, R., \& Go, F.M. (2004). Projected destination image online: website content analysis of pictures and text. Information Technology and Tourism, 7(2), 73-89.

Gretzel, U., Yuan, Y., and Fesenmaier, D. R. (2000). Preparing for the New Economy: Advertising Strategies and Change in Destination Marketing Organizations. Journal of Travel Research, 39, 146-156.

Grün, C., Werthner, H., Proll, B., Retschitzegger, W., and Schwinger, W. (2008). Assisting tourists on the move - An evaluation of mobile tourist guides. Paper presented at the 7th International Conference on Mobile Business, ICMB 2008, Creativity and Convergence. 171 $-180$.

Gupta, D.D., \& Utkarsh. (2014). Assessing the website effectiveness of top ten tourist attracting nations. Information Technology Tourism,14,151-175.

Ha, M., and Love, C. (2005). Exploring Content and Design Factors Associated with Convention and Visitors Bureau Web Site Development: An Analysis of Recognition by Meeting Planners, Journal of Convention and Event Tourism, 7(1), 43-59.

Han, J., and Mills, J. E. (2006). Zero acquaintance benchmarking at travel destination websites: What is the first impression that national tourism organizations try to make? International Journal of Tourism Research, 8(6), 405-430.

Hays, S., Page, S.J., \& Buhalis, D. (2013). Social media as a destination marketing tool: its use by national tourism organizations. Current Issues in Tourism, 16(3), 211-239.

Hipperson, T. (2010). The changing face of data insight and its relationship to brand marketing. Journal of Database Marketing and Customer Strategy Management, 17(34), 262-266.

Ho, C. I., and Lee, Y. L. (2007). The development of an e-travel service quality scale. Tourism Management, 28(6), 1434 -1449.

Horng, Jeou-Shyan and Tsai, Chen-Tsang. (2010). Culinary tourism strategic development: an Asia-Pacific Perspective, International Journal of Tourism research, 14, 40-55.

Huertas, A., and Marine-Roig, E. (2015). Destination Brand Communication Through the Social Media: What Contents Trigger Most Reactions of Users? In Tussyadiah, A. Inversini (eds.), Information and Communication Technologies in Tourism. Proceedings of the International Conference in Lugano, Switzerland, February 3-6. 295-308.

Hyun, M., Lee, S., and Hu, C. (2009). Mobile-mediated virtual experience in tourism: concept, typology and applications. Journal of Vacation Marketing, 15(2), 149-164.

Jiménez-Barreto, J., and Campo- Martínez, S. (2018). Destination website quality, users' attitudes and the willingness to participate in online co-creation experiences. European Journal of Management and Business Economics. 27(1), 26-41.

Kaplan, A. M., and Haenlein, M. (2010). Users of the world, unite! The challenges and opportunities of Social Media, Business Horizons, 53(1), 59-68. 
Kaplanidou, K., and Vogt, C. (2006). Structural Analysis of Destination Travel Intentions as a Function of Web Site Features. Journal of Travel Research, 45, 204-216.

Karanasios, S., and Burgess, S. (2008). Tourism and Internet adoption: a developing world perspective. International Journal of Tourism Research, 10(2), 169-182.

Karanasios, S, Burgess, S and Sellitto, C. (2011) A classification of mobile tourism applications. In Ordóñez de Pablo, P., Tennyson, R. D. \& Zhao, J. (eds), Global Hospitality and Tourism Management Technologies, IGI Global, Hershley, United States, 165-177.

Kastenholz, E., Eusébio, C., and Carneiro, M. J. (2013). Studying factors influencing repeat visitation of cultural tourists. Journal of Vacation Marketing, 19(4), 343-358.

Kenteris, M., Gavalas, D., and Economou, D. (2009). An innovative mobile electronic tourist guide application. Personal and Ubiquitous Computing, 13, 103-118.

Kerr, G. (2006). From destination brand to local brand. Journal of Brand Management, 13 (4/5), 276-283.

Khan, M. (2014). Invest in Your Love: Romantic desires, YouTube videos, and the online marketing of Tahiti. Tourist Studies, 14(2), 144-167.

Kim, S., Shaw, T., and Schneider, H. (2003). Web site design benchmarking within industry groups. Internet Research: Electronic Networking Applications and Policy, 13(1), 17-26.

Kim, I., and Kuljis, J. (2010). Applying content analysis to web-based content. Journal of Computing and Information Technology, 4, 369-375.

Királ'ová, A. and Pavlíčeka, A. (2014). Development of Social Media Strategies in Tourism Destination. Development of Social Media Strategies in Tourism Destination. International Conference on Strategic Innovative Marketing, IC-SIM 2014, September 1-4, Madrid, Spain.

Kladou, S., and Mavragani, E. (2015). Assessing destination image: An online marketing approach and the case of TripAdvisor. Journal of Destination Marketing \& Management, 4(3) 187-193.

Kline, S. F., Morrison, A. M., and St. John A. (2004). Exploring Bed \& Breakfast Web Sites: A Balanced Scorecard Approach. Journal of Travel \& Tourism Marketing, 17(2/3), 253-67.

Labbaika, D.R. (2015). The Effective use of Social Media in Destination Branding, A bachelor thesis submitted to Urban, Port \& Transport Economics department, Erasmus University Rotterdam.

Litvin, S., Goldsmith, R. E., and Pan, B. (2008). Electronic word-of-mouth in hospitality and tourism management. Tourism Management, 29, 458-468.

Loureiro, S.M.C. (2015). The role of website quality on pad, attitude and intentions to visit and recommend island destination. International Journal of Tourism Research, 17(6), 545-554.

Luna-Nevarez, C., and Hyman, M. R. (2012). Common Practices in Destination Website Design. Journal of Destination Marketing \& Management, 1.1-2, 94-106.

Macias, W. (2010). A preliminary structural equation model of comprehension and persuasion of interactive advertising brand web sites. Journal of Interactive Advertising, 3(2), 36-48.

Mak, B., Nickerson, R., and Sim, J. (2015). A model of attitude toward mobile location-based services. Journal of Quality Assurance in Hospitality and Tourism, 16(4), 414-437.

Marchiori, E., Milwood, P., and Zach, F. (2013). Drivers and Benefits of Analysing DMOs' eWOM Activities. In Cantoni, L \& Xiang, Z. (eds), Information and Communication Technologies in Tourism, Proceedings of the International Conference in Innsbruck, Austria, January 22-25. 107-118.

Mavridis, T. and Symeonidis, A. L. (2014). Semantic analysis of web documents for the generation of optimal content. Engineering Applications of Artificial Intelligence, 35, 114 130. 
Míguez-González, M.I., and Fernández-Cavia, J. (2015). Tourism and online communication: interactivity and social web in official destination websites. Communication \& Society, 28(4), 17-31.

Morrison, A. M., Taylor, S. J., and Douglas, A. (2004). Web Site Evaluation in Tourism and Hospitality: The Art Is Not Yet Stated. Journal of Travel and Tourism Marketing, 17 (2/3), 233-251.

Morrison, A. (2013). Destination management and destination marketing: The platform for excellence in tourism destinations. Tourism Review, 28(1), 6-9.

Neti, S. (2011). Social Media and Its Role in Marketing. International Journal of Enterprise Computing and Business Systems, 1(2), 1-15.

Neuendorf, K. A. (2002). The Content Analysis Guidebook. Sage Publications, USA.

Palmer, A. (2005). The internet challenge for destination marketing organizations in Morgan, N., Pritchard, A., \& Pride, R. (eds). Destination Branding: Creating the Unique Destination Proposition. 2nd ed. Oxford: Elsevier, pp. 128-139.

Park, Y.A., Gretzel, U., and Sirakaya-Turkb, E. (2007). Measuring web quality for online travel agencies. Journal of Travel \& Tourism Marketing, 23(1), 15-30.

Pradiptarini, C. (2011). Social Media Marketing: Measuring Its Effectiveness and Identifying the Target Market. Wisconsin, Journal of Undergraduate research. University of Wisconsin-La Crosse.

Rincón, D. (2010). Urbes electrónicas: una estrategia de Citymarketing Global, Enlace: Revista Venezolana de Información. Tecnología y Conocimiento, 7(1), 45-59.

Roney, S. A., and Ozturan, M. (2006). A content analysis of the web sites of Turkish travel agencies, Anatolia: International Journal of Tourism and Hospitality Research, 17(1), 43-54.

Sartori, A., Mottironi, C., and Corigliano, M.A. (2012). Tourist destination brand equity and internal stakeholders: An empirical research. Journal of Vacation Marketing, 18(4), 327-340.

Scolari, C.A., \& Fernández-Cavia, J. (2014). Mobile Applications and Destination Branding in Spain. International Journal of Interactive Mobile Technologies, 8(2), 15-22.

Sevin, E. (2013). Places going viral: Twitter usage patterns in destination marketing and place branding. Journal of Place Management and Development, 6(3), 227-239.

Sharma, V., and Dogra, J. (2011). Synergism between online branding and promotion of tourism destination: review in the context of destination management organizations (DMOs). International Journal of Multidisciplinary Research, 1(6), 287- 299.

Sigala, M. (2009). Web 2.0, social marketing strategies and distribution channels for city destinations: Enhancing the participatory role of travelers and exploiting their collective intelligence. In Gascó-Hernández. M., \& Torres-Coronas. T, (Eds.), Information communication technologies and city marketing: Digital opportunities for cities around the world, 220-244.

Standing, C., Tang-Taye, J. P., \& Boyer, M. (2014). The impact of the Internet in travel and tourism: A research review 2001-2010. Journal of Travel \& Tourism Marketing, 31(1), 82113.

Stepchenkova, S., \& Zhan, F. (2013). Visual destination images of Peru: Comparative content analysis of DMO and user-generated photography. Tourism Management, 36(1), 590-601.

Stienmetz, J. L., Levy, S. E., \& Boo, S. (2012). Factors influencing the usability of mobile destination management organization websites. Journal of Travel Research, 52(4), 453-464.

Tanrisevdi, A., and Duran, N. (2011). Comparative Evaluation of the Official Destination Websites from the Perspective of Customers, Journal of Hospitality Marketing \& Management, 20(7), 740-76. 
Tolica, E.K., Gorica, K., Panajoti, V.H., and Pjero, E. (2017). The Role of Internet and SEO in Branding Destinations: Case of Albania as a New Destination in Balkans. Academic Journal of Interdisciplinary Studies, 6(1), 45-52.

Trueman, M., Klemm, M., and Giroud, A.(2004). Can a city communicate? Bradford as a corporate brand, Corporate Communications, 9(4), 317-330.

Tsang, N.K.F., Lai, M.T.H., and Law, R. (2010). Measuring e-service quality for online travel agencies. Journal of Travel \& Tourism Marketing, 27(23), 306-323.

Vijoli, C., and Marinescu, N. (2016). Analyzing the online promotion of a tourist destination: the case of Saariselkä, Bull 